\title{
Wybrane zagadnienia dotyczące wpływu dodatku wodoru do gazu ziemnego na elementy systemu gazowniczego
}

\section{Selected issues concerning the impact of hydrogen addition to natural gas on the gas network components}

\author{
Jacek Jaworski, Ewa Kukulska-Zając, Paweł Kułaga \\ Instytut Nafty i Gazu - Państwowy Instytut Badawczy
}

\begin{abstract}
STRESZCZENIE: W ostatnim czasie można zaobserwować rosnące zainteresowanie dodawaniem do sieci gazowej wodoru pochodzącego ze źródeł odnawialnych, tzn. technologią power-to-gas. Umożliwia ona przekształcenie wyprodukowanej energii elektrycznej do postaci wodoru i zmagazynowanie go w systemie gazowniczym. Technologia ta może stać się jednym z istotnych czynników zwiększenia udziału energii odnawialnej w całkowitym bilansie energetycznym. Skutkiem dodawania wodoru do gazu ziemnego będzie obecność w sieciach gazowych mieszaniny gazu ziemnego oraz wodoru, która siecią tą docierać będzie do odbiorców końcowych, w tym odbiorców w gospodarstwach domowych. Właściwości fizykochemiczne wodoru, takie jak np. gęstość właściwa czy lepkość, istotnie różnią się od właściwości fizykochemicznych składników gazu ziemnego, takich jak metan, etan, propan, butan, azot itd. W związku z powyższym właściwości mieszaniny gazowej po dodaniu do niej wodoru będą się znacznie różnić od właściwości obecnie stosowanego gazu ziemnego. Tym samym elementy systemu gazowniczego, a także odbiorniki gazu u odbiorców końcowych będą podlegać oddziaływaniu wodoru. Konieczne staje się zatem zapewnienie, że w granicach przewidywanych stężeń wodoru elementy systemu gazowniczego, a także odbiorniki gazu będą w stanie długotrwale pracować bez pogorszenia swych właściwości funkcjonalnych oraz zmniejszenia bezpieczeństwa technicznego. W niniejszym artykule omówiono wyniki dotychczasowych badań prowadzonych w INiG - PIB dotyczących wpływu mieszaniny gazu ziemnego i wodoru na: urządzenia gazowe użytku domowego oraz komercyjnego, rozliczenia i pomiary paliw gazowych, jakość paliw gazowych, gazomierze miechowe oraz reduktory średniego ciśnienia.
\end{abstract}

Słowa kluczowe: power-to-gas, PtG, P2G, wodór ze źródeł odnawialnych, gaz ziemny, infrastruktura gazociągowa, urządzenia gazowe.

\begin{abstract}
Recently, there has been a growing interest in adding hydrogen from renewable sources to the gas network, i.e. Powerto-Gas technology. This technology makes it possible to convert the produced electrical power into hydrogen and to store it in the gas network. It may become one of the significant factors of increasing the share of renewable energy in the overall energy mix. The addition of hydrogen to natural gas will result in the presence of a mixture of natural gas and hydrogen in the gas networks through which it will reach end users, including household customers. The physicochemical properties of hydrogen, such as specific density or viscosity, differ significantly from those of natural gas components, such as methane, ethane, propane, butane, nitrogen, etc. As a result, the properties of a gas mixture, after adding hydrogen, will be significantly different from those of the natural gas currently in use. Thus, both gas network components and gas appliances of end users will be exposed to hydrogen. It is therefore necessary to ensure long-period operation of gas network components and gas appliances, within the limits of anticipated hydrogen concentrations, without deterioration in their functional properties and technical safety. This paper discusses the results of research conducted at INiG - PIB in terms of resistance to a mixture of natural gas and hydrogen (up to 23\%) on: gas appliances for household and commercial use, gaseous fuels metering and billing, gaseous fuels quality, diaphragm gas meters and medium pressure regulators.
\end{abstract}

Key words: Power-to-Gas, PtG, P2G, renewable hydrogen, natural gas, gas pipeline infrastructure, gas appliances.

\section{Wprowadzenie}

Wodór to najprostszy pierwiastek chemiczny, który najczęściej występuje we wszechświecie. Stanowi około $80 \%$ atmosfery Słońca, na Ziemi jest go najwięcej w wodzie, która pokrywa około $70 \%$ powierzchni Ziemi, występuje też we wszelkiej materii organicznej. Wodór to doskonały nośnik energii oraz „czyste” paliwo, gdyż w wyniku jego spalania powstaje tylko energia i woda.

Jednym z istotnych czynników zwiększenia udziału energii

Autor do korespondencji: J. Jaworski, e-mail: jacek.jaworski@inig.pl

Artykuł nadesłano do Redakcji 04.09.2019 r. Zatwierdzono do druku 30.09.2019 r. 
odnawialnej w całkowitym bilansie energetycznym jest uzyskanie możliwości magazynowania wyprodukowanej energii. Pozyskana ze źródeł odnawialnych energia elektryczna może być przechowywana np. w postaci wodoru. Jako magazyny wytworzonego wodoru mogą być wykorzystywane istniejące sieci gazowe. Sieci gazowe pozwalają nie tylko na długotrwałe magazynowanie energii w postaci wodoru, ale także na przesyłanie wodoru (energii) z miejsca wytworzenia do miejsc najbardziej efektywnego jego wykorzystania. Stąd też w ostatnim czasie można zaobserwować rosnące zainteresowanie dodawaniem do istniejących sieci gazowych wodoru pochodzącego ze źródeł odnawialnych, czyli zainteresowanie projektami typu power-to-gas ( $\mathrm{PtG} / \mathrm{P} 2 \mathrm{G})$.

Przesyłanie wodoru gazociągami i możliwość dodawania wodoru do sieci gazowych są wciąż nowymi rozwiązaniami, wymagającymi badań, gdyż dotychczas zostały potwierdzone w niewielkiej liczbie przypadków. Ze względu na specyficzny zestaw właściwości fizykochemicznych wodoru jego transport sieciami gazowymi jest znacznie trudniejszy niż transport gazu ziemnego. Skutkiem dodawania wodoru do gazu ziemnego będzie obecność w sieciach gazowych mieszaniny gazu ziemnego oraz wodoru, która tymi sieciami docierać będzie do odbiorców końcowych, w tym odbiorców w gospodarstwach domowych.

Atom wodoru zbudowany jest $\mathrm{z}$ jednego protonu $\mathrm{i}$ jednego elektronu. Wodór tworzy bardzo trwałe czassteczki dwuatomowe, które w wysokich temperaturach rozpadają się na pojedyncze atomy. Jest najlżejszy ze wszystkich pierwiastków i gazów (niezależnie od stanu skupienia), 14 razy lżejszy od powietrza. Jego gęstość wynosi $0,082 \mathrm{~kg} / \mathrm{m}^{3}$ (gęstość gazu ziemnego wysokometanowego to w przybliżeniu $0,75 \mathrm{~kg} / \mathrm{m}^{3}$ ). Wodór to gaz bezbarwny, bezwonny i nietoksyczny, który nie rozpuszcza się w wodzie. Jest bardzo reaktywny, palny, a w połączeniu z tlenem tworzy mieszaninę wybuchową. W przeciwieństwie do paliw węglowych podczas spalania wodoru nie powstają szkodliwe produkty uboczne - powstaje tylko energia i czysta woda. Pierwiastek ten nie wywołuje kwaśnych deszczów, nie niszczy warstwy ozonowej ani nie tworzy szkodliwych emisji. Wykazuje dużą szybkość dyfuzji przez przegrody porowate, gumę, a nawet niektóre metale. Wodór charakteryzuje się też najwyższą wartością opałową odniesioną do jednostki masy $(119,9 \mathrm{MJ} / \mathrm{kg})$ w stosunku do innych paliw, tj. benzyny (43,2 MJ/kg), ON (41,8 MJ/kg), gazu ziemnego (38,2-47,2 MJ/kg) czy metanu (50,0 MJ/kg). Dodanie wodoru do gazu ziemnego spowoduje natomiast zmniejszenie wartości kalorycznej gazu odniesionej do jednostki objętości. Na rysunku 1 przedstawiono zmianę (spadek) wartości ciepła spalania gazu ziemnego o wartości wyjściowej $\mathrm{Hs}=37,9 \mathrm{MJ} / \mathrm{m}^{3}$ po dodaniu wodoru.

Należy zaznaczyć, że długość płomienia palącego się wodoru jest krótsza względem płomienia metanu, co jest efektem dużo większej szybkości spalania wodoru. $Z$ punktu widzenia

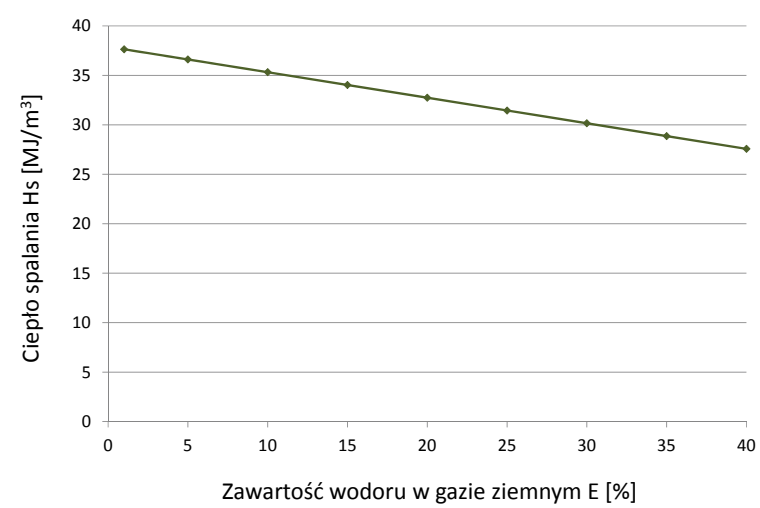

Rys. 1. Zależność ciepła spalania gazu ziemnego od zawartości wodoru

Fig. 1. Dependence of natural gas heating values on the hydrogen content

użytkowego trzeba także wspomnieć o granicach wybuchowości wodoru, które istotnie różnią się od metanu. Dolna granica wybuchowości (DGW) wynosi $4,1 \%$, podczas gdy dla metanu wynosi ona 4,5\%. Z kolei górna granica wybuchowości (GGW) wynosi $75 \%$, a dla metanu $15 \%$.

Jak wynika z powyższego, właściwości fizykochemiczne wodoru (np. gęstość, lepkość itd.) istotnie różnią się od właściwości fizykochemicznych składników gazu ziemnego, takich jak metan, etan, propan, azot itd. W związku z tym właściwości mieszaniny gazowej po dodaniu do niej wodoru będa się znacznie różnić od właściwości obecnie stosowanego gazu ziemnego. Tym samym elementy systemu gazowniczego, takie jak rury, zawory, zasuwy, kurki, kompensatory, przejścia, reduktory, osuszacze, gazomierze, przetworniki pomiarowe, aparatura kontrolna, a także odbiorniki gazu u odbiorców końcowych będą podlegać oddziaływaniu wodoru. Konieczne staje się zatem zapewnienie, że w granicach przewidywanych stężeń wodoru w sieciach gazowych - elementy systemu gazowniczego, a także odbiorniki gazu będą w stanie długotrwale pracować bez pogorszenia swych właściwości funkcjonalnych oraz zmniejszenia bezpieczeństwa technicznego. W publikacjach zagranicznych można znaleźć cząstkowe informacje na temat analiz wpływu wodoru na elementy sieci i instalacji gazowych, niemniej jednak nie istnieje pełne kompendium wiedzy, które dawałoby odpowiedź na podstawowe pytanie, tj. w jakim stopniu dodatek wodoru do gazu ziemnego jest bezpieczny dla wszystkich elementów systemu gazowniczego i odbiorców końcowych. W obszarze tym ciągle prowadzone są badania przez różne jednostki naukowo-badawcze. Problematyka wpływu wodoru na infrastrukturę gazową, ze szczególnym uwzględnieniem kwestii materiałowych, została omówiona np. w publikacjach takich autorów jak: Van der Zwaan et al. (2011), Dodds i Demoullin (2013), Durbin i Malardier-Jugroot (2013), Melaina et al. (2013), Messaoudani et al. (2016), Meng et al. (2017), Gondal (2019). 
Należy zwrócić uwagę na fakt, że elementy stosowane do budowy sieci gazowych czy odbiorniki gazu u odbiorców końcowych mogą różnić się co do właściwości w poszczególnych krajach. Tym samym uzyskanie odpowiedzi na dany problem w jednym kraju, np. dotyczący wpływu wodoru na określone rury stalowe, nie oznacza automatycznie rozwiązania problemu w innych krajach.

W Europie w ramach projektu NATURALHY prowadzone były prace na potrzeby realizacji zagadnień badawczych związanych $\mathrm{z}$ dodawaniem wodoru do sieci. Stanowiska badawcze skierowane były ściśle na konkretny zakres prac i ograniczone do lokalnego zastosowania. Np. duńskie przedsiębiorstwo gazownicze wraz z przemysłem podjęło badania nad urządzeniami sieciowymi do transportu wodoru, gazomierzami oraz systemami do kontroli, regulacji i monitorowania tych urządzeń. Wybudowano miniaturową sieć gazową wykonaną z rur stalowych oraz z rur z tworzywa sztucznego stosowanych w istniejącej sieci dystrybucyjnej gazu, zgodnie z obowiązującymi normami i przepisami kopenhaskiej spółki gazu ziemnego (HNG). Badania ograniczyły się do dwóch zakresów ciśnienia: 19 bar (dla rur stalowych) oraz 4 bar (dla rur z PE). Jako jeden z wniosków wskazano konieczność dalszych badań, m.in. tendencji do zwiększonej sztywności tworzyw polimerowych PEM i zmniejszonej sztywności tworzywa PE 100 (Iskov, 2010). W ramach projektu NATURALHY firma GDF Suez zbadała trzy gazomierze miechowe do pomiaru mieszaniny 50:50 $\mathrm{CH}_{4} / \mathrm{H}_{2}$ (Melaina et al., 2013).

Na świecie tego typu prace badawcze są również podejmowane. Gas Technology Institute (GTI) w USA analizował degradację materiałów, wycieków wodoru i dokładności gazomierzy przy zastosowaniu mieszanin gazu ziemnego i wodoru, aby przeprowadzić ocenę wpływu wodoru na materiały rurociągów dystrybucyjnych. Ponadto GTI dokonał przeglądu materiałów stosowanych do budowy rurociągów, wykorzystując dane z systemu dystrybucji opublikowane przez Department of Transportation (DOT) i źródła literaturowe GTI. Dzięki połączeniu informacji literaturowych dotyczących materiałów do budowy rurociągów oraz warunków pracy systemu dystrybucji gazu ziemnego - GTI ocenił trwałość infrastruktury dystrybucji gazu ziemnego w USA w związku z potencjalnym transportem mieszanin gazu ziemnego $\mathrm{z}$ wodorem. $\mathrm{W}$ ramach projektu zostały m.in. przetestowane trzy gazomierze $\mathrm{z}$ membranami polimerowymi przy użyciu dwóch mieszanin gazowych (pierwsza: 100\% metanu, druga: 50\% wodoru i 50\% metanu) (Zhou i Ersoy, 2010).

Gondal (2019) wskazuje, że wśród urządzeń końcowych znajdują się między innymi silniki pojazdów samochodowych, palniki i kocioł, które są w stanie poprawnie pracować przy 20-procentowym stężeniu wodoru, podczas gdy kuchenki gazowe i aplikacje CHP są odporne nawet na 50-procentowy dodatek wodoru do gazu ziemnego.
Zhao et al. (2019) przedstawili w swojej publikacji wyniki badań płyt kuchennych przy zasilaniu różnymi mieszankami gazu ziemnego i wodoru. Badano takie parametry jak: limity cofania, czas zapłonu, charakterystyka płomienia, wydajność gotowania, hałas spalania, temperatura palnika i różne emisje ( $\mathrm{NO}, \mathrm{NO}_{2}, \mathrm{~N}_{2} \mathrm{O}, \mathrm{CO}$, niespalone węglowodory (UHC), $\mathrm{NH}_{3}$ ). Na podstawie wyników badań stwierdzono, że wydajność spalania palnika na płycie kuchennej nie zmienia się znacząco po dodaniu wodoru do około $15 \%$ objętościowych, co pokazuje wykonalność wykorzystania wodoru w istniejących urządzeniach kuchennych bez żadnych modyfikacji. Metodologie eksperymentu i wyniki tego badania będą służyć jako odniesienie do przyszłych norm badań i regulacji emisji dotyczących palników domowych.

Porównanie powyższych wyników, w połączeniu z wynikami INiG - PIB, wskazuje na konieczność przeprowadzenia własnych badań elementów systemu gazowniczego.

\section{Wodór w świetle polityk krajowych i unijnych}

W unijnym i polskim porządku prawnym funkcjonują już przepisy stwarzające podstawy badań, użytkowania i popularyzowania paliw alternatywnych takich jak wodór. Unia Europejska w swojej polityce energetycznej kładzie duży nacisk na zmniejszanie emisji gazów cieplarnianych oraz na rozwój innowacyjnych technologii.

Technologia PtG wpisuje się w politykę energetyczną Polski do 2030 roku (Obwieszczenie z 21 grudnia 2010 r.), której jednym z priorytetów jest osiągnięcie $w$ roku 2020 co najmniej 15-procentowego udziału energii ze źródeł odnawialnych w zużyciu finalnym energii brutto. Takie zobowiązanie wynika bezpośrednio z Dyrektywy Parlamentu Europejskiego i Rady 2009/28/WE z dnia 23 kwietnia 2009 r. w sprawie promowania stosowania energii ze źródeł odnawialnych, zmieniającej i w następstwie uchylającej dyrektywy 2001/77/WE oraz 2003/30/WE (Dyrektywa 2009/28/WE). Dyrektywa ta ma znaczący wpływ na sektor energetyczny, kierunki jego rozwoju i prowadzenia badań. Jednym z istotnych czynników zwiększenia udziału energii odnawialnej w całkowitym bilansie energetycznym jest uzyskanie możliwości magazynowania wyprodukowanej energii, w tym poprzez wykorzystanie technologii PtG.

Wykorzystanie wodoru wytworzonego przy użyciu energii ze źródeł odnawialnych do celów obliczenia udziału energii z OZE w końcowym zużyciu energii brutto wskazuje również Dyrektywa Parlamentu Europejskiego i Rady (UE) 2018/2001 z dnia 11 grudnia 2018 r. w sprawie promowania stosowania energii ze źródeł odnawialnych (Dyrektywa 2018/2001). Dyrektywa ta określa wiążący unijny cel ogólny w odniesieniu do całkowitego udziału energii ze źródeł odnawialnych 
w końcowym zużyciu energii brutto w Unii w 2030 r. Ustanawia również zasady dotyczące m.in. wsparcia finansowego na rzecz energii elektrycznej ze źródeł odnawialnych oraz dotyczące prosumpcji takiej energii elektrycznej, jak również wykorzystania energii ze źródeł odnawialnych w sektorze ogrzewania i chłodzenia oraz w sektorze transportu.

Wodór jako paliwo alternatywne został także uwzględniony w art. 2 Dyrektywy Parlamentu Europejskiego i Rady z dnia 22 października 2014 roku w sprawie rozwoju infrastruktury paliw alternatywnych (Dyrektywa 2014/94/UE). Dyrektywa ta podkreśla jednak konieczność zbudowania nowych sieci infrastruktury paliwowej w tym zakresie.

Wodór znajduje się obecnie również w centrum polityki energetycznej Polski, zwłaszcza że Polska jest jednym z jego największych producentów w Europie. Istotnym dokumentem w tym zakresie jest Strategia na rzecz Odpowiedzialnego Rozwoju do roku 2020 (z perspektywą do 2030 r.) (SOR). Strategia określa podstawowe uwarunkowania, cele i kierunki rozwoju kraju w wymiarze społecznym, gospodarczym, regionalnym i przestrzennym w perspektywie lat 2020 i 2030. SOR przedstawia nowy model rozwoju - rozwój odpowiedzialny oraz społecznie i terytorialnie zrównoważony. W SOR zostały wymienione tzw. Programy Pierwszej Prędkości, wśród których znalazły się m.in. wysokosprawne, niskoemisyjne i zintegrowane układy wytwarzania, magazynowania, przesyłu i dystrybucji energii (KIS 7). To te programy mają otrzymać dodatkowe wsparcie w postaci odpowiedniego, szybkiego finansowania ich rozwoju.

Jednym z obszarów wpływających na osiągnięcie celów SOR jest oczywiście energia. Wzrost konkurencyjności polskiego przemysłu oraz zapewnienie bezpieczeństwa dostaw energii mają zostać osiągnięte poprzez modernizację sektora energetycznego oraz podjęcie działań na rzecz dywersyfikacji źródeł energii i zwiększenia efektywności energetycznej. Zgodnie z SOR poprawę bezpieczeństwa energetycznego kraju można osiągnać poprzez rozwijanie technologii magazynowania energii (w różnych postaciach), a także budowę, rozbudowę i modernizację sieci gazowej przesyłowej i dystrybucyjnej oraz podziemnych magazynów gazu. Natomiast poprawę efektywności energetycznej można będzie uzyskać poprzez wsparcie dla strategii nisko- i zeroemisyjnych.

Drugim istotnym dokumentem poruszającym kwestie możliwości wykorzystania wodoru jest projekt Polityki energetycznej Polski do 2040 roku (PEP2040). Projekt PEP zawiera opis stanu i uwarunkowań sektora energetycznego, wyznacza główny cel polityki energetycznej i określa jej osiem głównych kierunków wraz z wyspecyfikowaniem celu danego kierunku oraz ze wskazaniem konkretnych działań realizacyjnych służących osiąganiu zamierzonego celu głównego. Zgodnie z projektem PEP głównym celem polityki energetycznej Polski jest „,bezpieczeństwo energetyczne, przy zapewnieniu konkurencyjności gospodarki, efektywności energetycznej i zmniejszeniu oddziaływania sektora energii na środowisko, przy optymalnym wykorzystaniu własnych zasobów energetycznych". W dokumencie tym wodór imiennie wskazany jest jako paliwo alternatywne, którego zwiększone wykorzystanie wpłynie na uniezależnienie się od dostaw ropy naftowej z jednego kierunku, oraz jako paliwo (inne niż OZE), które może być wykorzystywane w transporcie.

Badania w obszarze technologii wodorowych, w tym PtG, wpisują się również doskonale w najważniejsze wyzwania społeczne zdefiniowane w programie ramowym Unii Europejskiej w zakresie badań naukowych i innowacji „Horyzont 2020” (Program Ramowy Horyzont 2020) oraz projektowanym programie Horyzont Europa. Wśród siedmiu unijnych wyzwań priorytetowych, w ramach których ukierunkowane inwestycje w badania naukowe i innowacje mogą przynieść realne korzyści obywatelom, znajdują się: bezpieczna, czysta i efektywna energia; inteligentny, ekologiczny i zintegrowany transport oraz działania w dziedzinie klimatu, środowisko, efektywna gospodarka zasobami i surowce.

Jak wskazano powyżej, badania nad technologiami wodorowymi wpisują się w strategie wyznaczone przez krajowe i unijne akty prawne oraz rządowe dokumenty strategiczne, których celem jest ograniczanie negatywnego wpływu człowieka na środowisko naturalne i wdrażanie elementów zasad zrównoważonego rozwoju w skali lokalnej, krajowej i globalnej. Dalsze inwestycje w badania nad technologią PtG wydają się zatem jak najbardziej kluczowe i zasadne.

\section{Badania INiG - PIB}

W Instytucie Nafty i Gazu - Państwowym Instytucie Badawczym od kilku już lat prowadzi się badania pod kątem odporności elementów systemu gazowniczego na dodatek wodoru do gazu ziemnego.

Dotychczas zostały przeprowadzone badania wpływu dodatku wodoru do gazu ziemnego na: urządzenia gazowe użytku domowego oraz komercyjnego, rozliczenia i pomiary paliw gazowych, w tym aspekty dokładności wyznaczania współczynnika ściśliwości gazu z podwyższoną zawartością wodoru (Łach, 2016), jakość paliw gazowych, gazomierze miechowe oraz reduktory średniego ciśnienia. Obecnie kontynuowane są badania gazomierzy miechowych i reduktorów średniego ciśnienia gazu oraz prowadzone są nowe badania dotyczące wpływu dodatku wodoru do gazu ziemnego na: jakość i bezpieczeństwo nawonienia paliw gazowych, gazomierze termiczne oraz szczelność połączeń mechanicznych elementów sieci i instalacji gazowych. 


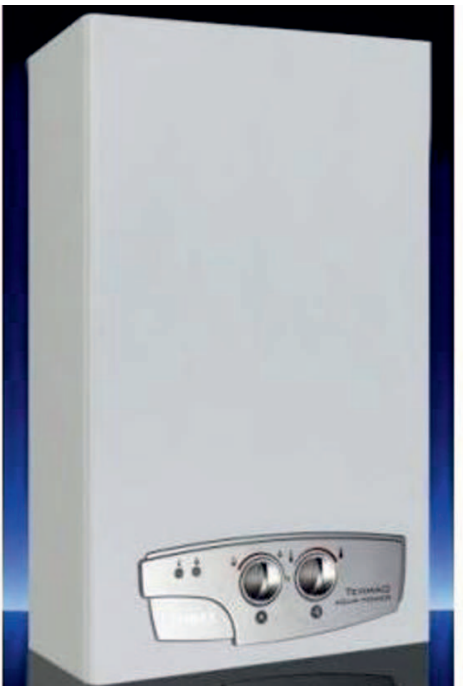

Krótki opis zrealizowanych do tej pory $\mathrm{w}$ INiG - PIB prac badawczych w zakresie badania wpływu dodatku wodoru do gazu ziemnego na elementy systemu gazowniczego przedstawiono poniżej.

\section{Ocena jakości paliw gazowych w kontekście wprowadzania wodoru do sieci gazowych}

(Schuster et al., 2019)

Maksymalny udział wodoru w mieszaninach gaz ziemny-wodór obliczono z użyciem sześciu różnych wariantów, opartych na dostępnych dokumentach prawnych, normalizacyjnych i technicznych. Obliczenia przeprowadzono dla łącznie ponad 3000 składów gazu, w tym gazów grupy E, Lw, Ls oraz gazów LNG.

Z wykonanych obliczeń i analiz wynika, że maksymalna zawartość wodoru w mieszaninie gaz ziemny-wodór pod względem prowadzenia oceny jakości tego typu mieszanin, która nie wpływa na niedotrzymanie opisanych w dokumentach odniesienia parametrów energetycznych gazu (głównie liczby Wobbego), nie powinna przekraczać 36\%. Prowadzenie oceny jakości tego typu mieszanin wymaga jednak stosowania odpowiednich metod analitycznych, innych niż wykorzystywane do tej pory rutynowo dla gazu ziemnego, oraz odpowiednio dobranych metod obliczeniowych służących do obliczania parametrów energetycznych mieszaniny.

\section{Analiza wplywu dodatku wodoru do gazu ziemnego na prace domowych i komercyjnych urzadzeń gazowych}

(Wojtowicz, 2019)

Badania urządzeń gazowych (kuchenki, ogrzewacze przepływowe wody, kotły, promienniki itp.) przeprowadzono dla trzech mieszanin gazu ziemnego wysokometanowego - z dodatkiem 10\%, 15\% i 23\% wodoru. Mieszaniny użyte w tych oraz pozostałych badaniach zostały wytworzone we własnej mieszalni gazów. W badanych urządzeniach sprawdzano następujące parametry: znamionowe obciążenie cieplne przy ciśnieniu nominalnym, sprawność cieplną, stężenia CO, NOx i niedopał (CnHm) przy ciśnieniu maksymalnym i przy obciążeniu zredukowanym oraz stabilność płomienia. Na podstawie przeprowadzonych badań można stwierdzić, że maksymalna ilość wodoru, jaką można zatłoczyć do gazu ziemnego wysokometanowego, aby powstałą mieszaninę można było bezpiecznie spalać w domowych i komercyjnych urządzeniach gazowych bez konieczności dokonywania jakichkolwiek zmian w ich konstrukcji, to $23 \%$. Natomiast aby powstałą mieszaninę bezpiecznie i efektywnie spalać, dodatek wodoru nie powinien przekraczać $15 \%$.

\section{Analiza wplywu dodatku wodoru do gazu ziemnego na pracę reduktorów średniego ciśnienia}

W pracy sprawdzono poprawność działania reduktorów średniego ciśnienia (zarówno nowych, jak i po 10 latach eksploatacji) po badaniach trwałości przy zastosowaniu jako medium zasilającego mieszaniny gazu ziemnego wysokometanowego z dodatkiem 15\% wodoru. W pracy wykonano również badania odporności chemicznej, polegające na określeniu wpływu gazu wysokometanowego z domieszką wodoru

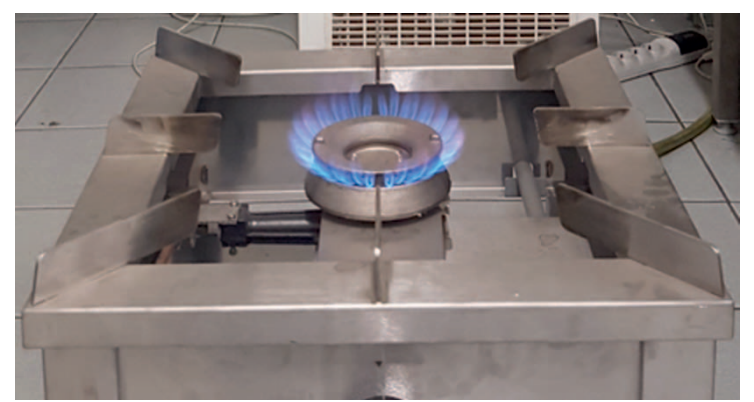

Rys. 3. Widok płomienia mieszaniny gazu ziemnego z 15-procentowym dodatkiem wodoru

Fig. 3. View of flame of a natural gas mixture with $15 \%$ hydrogen addition 
na materiały elastomerowe reduktorów. Na podstawie przeprowadzonych badań można stwierdzić, że mieszanina gazu ziemnego z 15-procentowym dodatkiem wodoru nie miała negatywnego wpływu na reduktory średniego ciśnienia. $\mathrm{Na}$ rysunku 3 przedstawiono widok płomienia mieszaniny gazu ziemnego z 15-procentowym dodatkiem wodoru. Należy zauważyć, że płomień takiej mieszaniny jest nieco krótszy od płomienia powstałego przy spalaniu samego gazu ziemnego.

\section{Wpływ dodatku wodoru do gazu ziemnego na bezpieczeństwo eksploatacji i dokładność wskazań gazomierzy miechowych}

W ramach pracy wykonano badania trwałości gazomierzy miechowych (zarówno nowych, jak i po 10-letniej eksploatacji) dwóch polskich producentów, które najczęściej występują w sieci gazowej. Badania pozwoliły określić, czy dodatek wodoru wpływa istotnie na błędy gazomierzy przy długotrwałym oddziaływaniu na układ pomiarowy gazomierza. Realizacja pracy wymagała zaprojektowania i budowy stanowiska do badania trwałości gazomierzy przy różnych zawartościach wodoru w gazie wysokometanowym: 0\%, 5\%, 10\% oraz $15 \%$. Wykonano również badania odporności chemicznej membran gazomierzy w środowisku gazu z 15-procentową zawartością wodoru oraz sprawdzono bezpieczeństwo użytkowania poprzez ocenę szczelności zewnętrznej gazomierzy. $\mathrm{Na}$ podstawie przeprowadzonych dotychczas badań nie odnotowano wpływu wodoru na charakterystykę gazomierzy oraz bezpieczeństwo ich użytkowania do zawartości 15\% $\mathrm{H}_{2} \mathrm{w}$ gazie. W przypadku stwierdzenia w przyszłości wpływu wodoru na

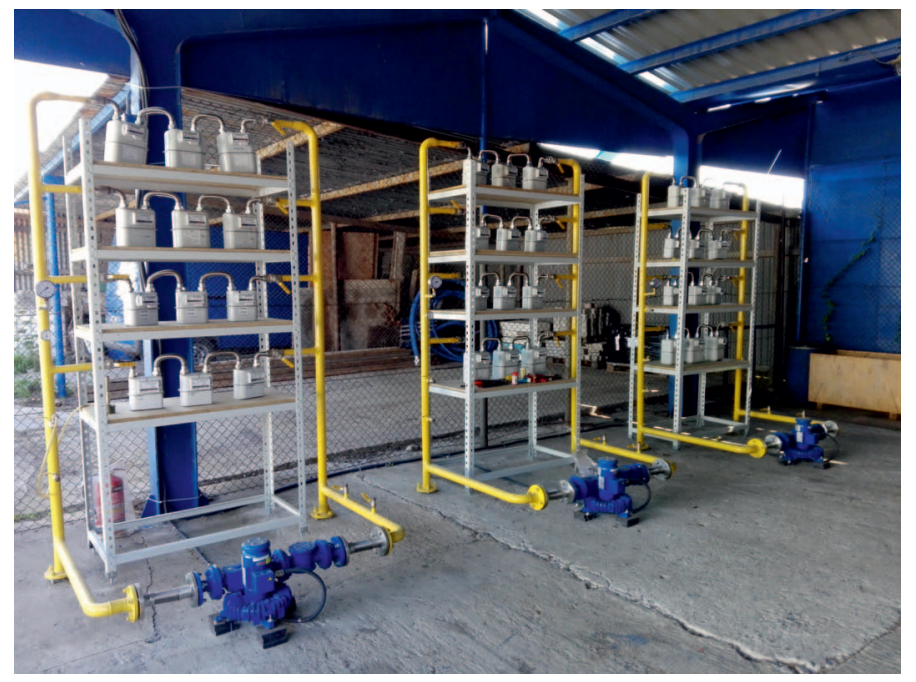

Rys. 4. Widok instalacji badawczej do badania trwałości gazomierzy z użyciem mieszaniny gazu ziemnego z wodorem

Fig. 4. View of the research installation for testing gas meter durability using a mixture of natural gas and hydrogen poprawność działania gazomierzy miechowych konieczne stanie się zmodyfikowanie modelu doboru gazomierzy przez operatora systemu dystrybucyjnego (Matusik i Jaworski, 2017).

\section{Rozliczenia w jednostkach energii paliw gazowych wzbogaconych o wodór}

W ramach pracy przeprowadzono analizę dostępnych danych dotyczących urządzeń wykorzystywanych w obrębie sieci dystrybucyjnej (gazomierzy, przetworników ciśnienia i temperatury, przeliczników objętości gazu i innych urządzeń przeznaczonych do stosowania w strefach zagrożonych wybuchem) do prowadzenia pomiarów rozliczeniowych oraz wskazano obszary i urządzenia, w przypadku których obecność wodoru w mierzonym gazie może wpływać na poprawność działania oraz zakres zastosowania. Oceniono także możliwość dostosowania obecnych układów pomiarowych do pomiarów mieszanin gazu ziemnego z wodorem wraz z oszacowaniem kosztów oraz wskazano niezbędne inwestycje w zakresie dostosowania istniejących układów pomiarowych do pomiarów rozliczeniowych gazu ziemnego wzbogaconego wodorem. W wyniku przeprowadzonych analiz, badania literaturowego i badań własnych określono dwa poziomy dopuszczalnej zawartości wodoru w mieszaninach z gazami ziemnymi:

- $10 \%$ - ze względu na dopuszczalną metodę przeliczania współczynnika ściśliwości;

- $8 \%$ - ze względu na bezpieczeństwo przeciwwybuchowe urządzeń pomiarowych przeznaczonych do stosowania w strefie zagrożenia wybuchem.

\section{Podsumowanie}

Jednym z istotnych czynników zwiększenia udziału energii odnawialnej w całkowitym bilansie energetycznym jest uzyskanie możliwości magazynowania wyprodukowanej energii. Taką możliwość zapewnia technologia power-to-gas, stąd też wskazany jest dalszy jej rozwój. Rozwój ten zależy w dużej mierze od dostępności OZE oraz polityki danego kraju względem OZE. Pozyskana ze źródeł odnawialnych energia elektryczna może być magazynowana np. poprzez konwersję do postaci wodoru, a jako magazyny wytworzonego wodoru moga być wykorzystywane istniejące sieci gazowe. Dodawanie wodoru do sieci gazu ziemnego wiąże się z nowymi wyzwaniami, wymagającymi dalszych badań w celu zapewnienia bezpieczeństwa pracy sieci gazowych oraz odbiorców gazu.

Zbiór informacji pozyskany w wyniku prowadzonych w INiG - PIB prac badawczych stanowi unikalną bazę danych, która budzi szerokie zainteresowanie wśród przedsiębiorstw gazowniczych czy też producentów wyrobów stosowanych do budowy sieci gazowych. 
Na podstawie przeprowadzonych dotychczas badań można stwierdzić, że maksymalna ilość wodoru, jaką można dodać do gazu ziemnego wysokometanowego, aby powstałą mieszaninę można bezpiecznie spalać w domowych i komercyjnych urządzeniach gazowych bez konieczności dokonywania jakichkolwiek zmian w ich konstrukcji, mierzyć ilość gazu i go rozliczać, wynosi do:

- 36\% - ze względu na wymagania dotyczące parametrów energetycznych gazu (jakość gazu) zawarte w dokumentach odniesienia;

- $23 \%$ - ze względu na bezpieczeństwo spalania w urządzeniach końcowych;

- $15 \%$ - ze względu na bezpieczne i efektywne spalanie w urządzeniach końcowych;

- $10 \%$ - ze względu na dopuszczalną metodę przeliczania współczynnika ściśliwości;

- $8 \%$ - ze względu na bezpieczeństwo przeciwwybuchowe urządzeń przeznaczonych do stosowania w strefie zagrożenia wybuchem.

Niemniej jednak prowadzone badania mają określony zakres stosowania, wynikający m.in. z zakresu wykorzystywanych ciśnień czy też populacji badanych próbek, co powoduje, że uzyskane wyniki badań nie mają charakteru statystycznego, a tym samym przedstawione w artykule dopuszczalne poziomy dodatku wodoru do gazu ziemnego mają charakter wstępny i mogą ulec zmianie. Uwzględniając powyższe, należy podkreślić konieczność prowadzenia dalszych badań wpływu mieszaniny gazu ziemnego z wodorem na poszczególne elementy systemu gazowniczego. W INiG - PIB kontynuowane są badania gazomierzy miechowych i reduktorów średniego ciśnienia gazu. Prowadzone są także nowe badania dotyczące wpływu dodatku wodoru do gazu ziemnego na jakość i bezpieczeństwo nawonienia paliw gazowych, a także badania dotyczące gazomierzy termicznych oraz badania związane ze szczelnością połączeń mechanicznych elementów sieci i instalacji gazowych. Wyniki tych badań powinny być znane i opublikowane w najbliższym czasie. Jedną ze specyficznych cech odnawialnych źródeł energii jest ich praca ze zmienną wydajnością, co z kolei może objawiać się dodawaniem wodoru do gazu ziemnego nie na stałym poziomie. Jeśli zmienność ta będzie mieściła się w granicach zaprezentowanych limitów, nie powinno to generować dodatkowych wyzwań. Niemniej jednak obszar ten mógłby być przedmiotem dalszych badań.

Zatłaczanie wodoru do sieci gazu ziemnego powinno być także uregulowane prawnie, co pozwoli na zapewnienie bezpieczeństwa transportu i użytkowania mieszanin gaz ziemny-wodór.

Autorzy pragna szczególnie podziękować Polskiej Spółce Gazownictwa Sp. z o.o. Oddział Zakład Gazowniczy w Warszawie oraz Oddział Zakład Gazowniczy w Krakowie za udostepnienie urządzeń pomiarowych oraz redukcyjnych z eksploatacji do badań.

Artykuł powstał między innymi na podstawie pracy statutowej pt. Wptyw dodatku wodoru do gazu ziemnego na bezpieczeństwo eksploatacji i dokładność wskazań gazomierzy miechowych - praca INiG - PIB na zlecenie MNiSW; nr zlecenia: 0057/GM/2018, nr archiwalny: DK-4100-0057/2018, oraz artykułu pt. Nadchodzi czas wodoru (Rynek Polskiej Nafty i Gazu, 2019: 14, ISSN 1896-4702).

\section{Literatura}

Dodds P.E., Demoullin S., 2013. Conversion of the UK gas system to transport hydrogen. International Journal of Hydrogen Energy, 38(18): 7189-7200. DOI: 10.1016/j.ijhydene.2013.03.070.

Durbin D.J., Malardier-Jugroot Cecile, 2013. Review of hydrogen storage techniques for on board vehicle applications. International Journal of Hydrogen Energy, 38(34): 14595-14617. DOI: 10.1016/j.ijhydene.2013.07.058.

Gondal I.A., 2019. Hydrogen integration in power-to-gas networks. International Journal of Hydrogen Energy, 44(3): 1803-1815. DOI: 10.1016/j.ijhydene.2018.11.164.

Iskov H., 2010. Field test of hydrogen in the natural gas grid. Project Report August 2010, EFP05 J. no. 033001/33031-0053, Danish Gas Technology Centre.

Łach M., 2016. Dokładność wyznaczania współczynnika ściśliwości gazu z podwyższoną zawartością wodoru - porównanie metod obliczeniowych. Nafta-Gaz, 5: 329-338. DOI: 10.18668/ NG.2016.05.04.

Matusik J., Jaworski J., 2017. Optymalny dobór gazomierzy miechowych przez operatora systemu gazowniczego. Nafta-Gaz, 4: 287-292. DOI: 10.18668/NG.2017.04.08.

Melaina M.W., Antonia O., Penev M., 2013. Blending hydrogen into Natural Gas Pipeline Networks: A review of key issues. Technical Report NREL/TP-5600-51995, March 2013.

Meng B. 2017. Hydrogen effects on X80 pipeline steel in high-pressure natural gas/hydrogen mixtures. International Journal of Hydrogen Energy, 42(11): 7404-7412. DOI: 10.1016/j.ijhydene.2016.05.145

Messaoudani Z.L., Rigas F., Hamid B.D.M., Hassan C.RC., 2016. Hazards, safety and knowledge gaps on hydrogen transmission via natural gas grid: a critical review. International Journal of Hydrogen Energy, 41(39): 17511-17525. DOI: 10.1016/j.ijhydene.2016.07.171.

Schuster T., Holewa-Rataj J., Kukulska-Zając E., 2019. Ocena jakości paliw gazowych w kontekście wprowadzania wodoru do sieci gazu ziemnego. Gaz, Woda i Technika Sanitarna: 42-46. DOI: 10.15199/17.2019.2.1.

Wojtowicz R., 2019. Analiza wpływu dodatku wodoru do gazu ziemnego na pracę urządzeń gazowych. Nafta-Gaz, 8: 465-473. DOI: 10.18668/NG.2019.08.03.

Zhao Y., McDonell V., Samuelsen S., 2019. Influence of hydrogen addition to pipeline natural gas on the combustion performance of a cooktop burner. International Journal of Hydrogen Energy, 44(23): 12239-12253. DOI: 10.1016/j.ijhydene.2019.03.100.

Zhou Z., Ersoy D., 2010. Review Studies of Hydrogen Use in Natural Gas Distribution Systems. Final report GTI Project Number 21029, Oct. 15, 2010.

van der Zwaan B.C.C., Schoots K., Rivera-Tinoco R., Verbong G.P.J., 2011. The cost of pipelining climate change mitigation: an overview of the economics of $\mathrm{CH}_{4}, \mathrm{CO}_{2}$ and $\mathrm{H}_{2}$ transportation. Applied Energy, 88(11): 3821-3831. DOI: 10.1016/j.apenergy.2011.05.019. 


\section{Akty prawne i normatywne}

Dyrektywa Parlamentu Europejskiego i Rady 2009/28/WE z dnia 23 kwietnia 2009 r. w sprawie promowania stosowania energii ze źródeł odnawialnych zmieniająca i w następstwie uchylająca dyrektywy 2001/77/WE oraz 2003/30/WE (Dz.Urz. UE L 140/16 z 5.06.2009).

Dyrektywa Parlamentu Europejskiego i Rady 2014/94/UE z dnia 22 października $2014 \mathrm{r}$. w sprawie rozwoju infrastruktury paliw alternatywnych (Dz.Urz. UE L 307/1 z 28.10.2014).

Dyrektywa Parlamentu Europejskiego i Rady (UE) 2018/2001 z dnia 11 grudnia 2018 r. w sprawie promowania stosowania energii ze źródeł odnawialnych (wersja przekształcona) (Dz.Urz. UE L 328/82 z 21.12.2018).

Obwieszczenie Ministra Gospodarki z dnia 21 grudnia 2009 r. w sprawie polityki energetycznej państwa do 2030 r. (M.P. z 2010 r. nr 2, poz. 11).

Polityka energetyczna Polski do 2040 roku (PEP2040) - projekt w. 1.2 - 23.11.2018. Ministerstwo Energii, Warszawa 2018.

Program Ramowy Unii Europejskiej Horyzont 2020.

Strategia na rzecz Odpowiedzialnego Rozwoju do roku 2020 (z perspektywą do 2030 r.). Załącznik do uchwały nr 8 Rady Ministrów z dnia 14 lutego 2017 r. (poz. 260).

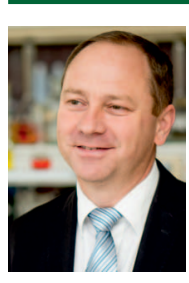

Dr inż. Jacek JAWORSKI

Adiunkt; zastępca Dyrektora ds. Gazownictwa

Instytut Nafty i Gazu - Państwowy Instytut Badawczy

ul. Lubicz 25 A

31-503 Kraków

E-mail: jacek.jaworski@inig.pl

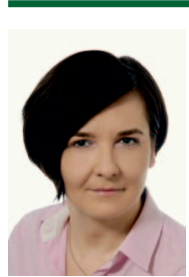

Dr Ewa KUKULSKA-ZAJĄC

Adiunkt; kierownik Zakładu Ochrony Środowiska

Instytut Nafty i Gazu - Państwowy Instytut Badawczy

ul. Lubicz 25 A

31-503 Kraków

E-mail:kukulska@inig.pl

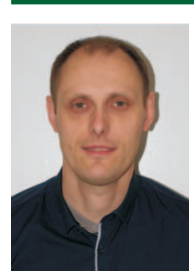

Mgr inż. Paweł KUŁAGA

Główny specjalista inżynieryjno-techniczny; kierownik Zakładu Metrologii Przepływów Instytut Nafty i Gazu - Państwowy Instytut Badawczy ul. Lubicz 25 A

31-503 Kraków

E-mail: pawel.kulaga@inig.pl

\section{OFERTA BADAWCZA ZAKKADU} METROLOGII PRZEPEYWÓW

prace badawcze dla przedsiębiorstw gazowniczych z zakresu dokładności i bezpieczeństwa pomiaru objętości gazu (badania jakośc gazomierzy, szacowanie nierozliczonych ilości gazu, analizy systemów rozliczeniowych, analizy stacji gazowych, szacowanie niepewności pomiaru, w tym na potrzeby emisji $\mathrm{CO}_{2}$ ):

badania w ramach akredytacii PCA nr AB 041 (w tym na potrzeby oceny zgodności z dyrektywą MID (Modut B) nr 2014/32/U - Jednostka Notyfikowana nr 1450):

» gazomierzy rotorowych, zgodnie z PN-EN 12480,

» gazomierzy turbinowych, zgodnie z PN-EN 12261,

" gazomierzy miechowych, zgodnie z PN-EN 1359 (w tym badania odporności gazomierzy miechowych na działanie magnesów neodymowych),

» gazomierzy miechowych, turbinowych, rotorowych, ultradźwiekkowych oraz termicznych masowych zgodnie z OIML R137-1\&2:2012,

» przeliczników objętości, przetworników ciśnienia i temperatury oraz czujników platynowych termometrów rezystancyjnych, zgodnie z PN-EN 12405-1;

badanie odporności gazomierzy na zanieczyszczenia pytowe i glikol (EN 16314):

badania w ramach akredytacji PCA nr AB 041 odporności: powtok ochronnych na korozię, na mgtę solną, wilgotność, uderzenie, zarysowanie, odporności chemicznej na ciecze;

badania w ramach akredytacji PCA nr AB 041 przyłączy do gazomierzy miechowych, szafek gazowniczych z wyposażeniem (na potrzeby krajowej oceny technicznej) i tączników do gazomierzy:

wzorcowanie, także w ramach akredytacji AP 152, gazomierzy, przeptywomierzy, ciśnieniomierzy, termometrów, przetworników pomiarowych ciśnienia i temperatury, mierników i kalibratorów wielkości elektrycznych (I, U, R);

badanie rejestratorów objętości i gazomierzy na zgodność protokołu komunikacyjnego ze standardem Smart-Gas;

ekspertyzy metrologiczne gazomierzy oraz ekspertyzy pod kątem nielegalnego poboru gazu;

działalność szkoleniowa dotycząca m.in. nielegalnego poboru gazu - metod wykrywania oraz przeciwdziatania w obszarze pomiarów u indywidualnych odbiorców.

Kierownik: mgr inż. Paweł Kułaga Adres: ul. Bagrowa 1, 30-733 Kraków Telefon: 126177426 Faks: 126531665 E- mail: pawel.kulaga@inig.pl

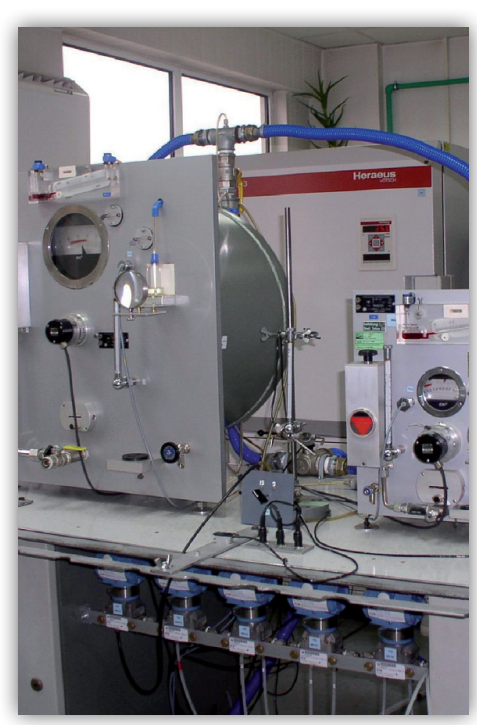

INSTYTUT NAFTY I GAZU

- Państwowy Instytut Badawczy 